U.S.Army

Coast. Eng. Res. Ctr.

$M R$ 78-2

(AD-A058 712)

\title{
An Annotated Bibliography
}

\section{of}

\section{CERC Coastal Ecology Research}

by

Edward J. Pullen, Robert M. Yancey,

Paul L. Knutson, and Arthur K. Hurme

MISCELLANEOUS REPORT NO. 78-2

MAY 1978
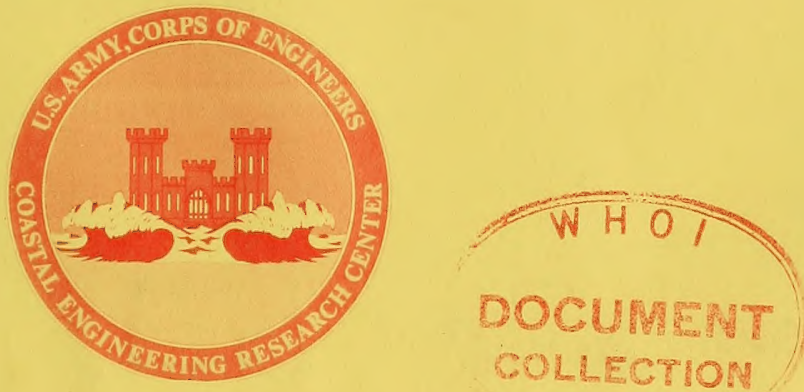

Approved for public release; distribution unlimited.

TC

203

.0581

MRT $78-2$

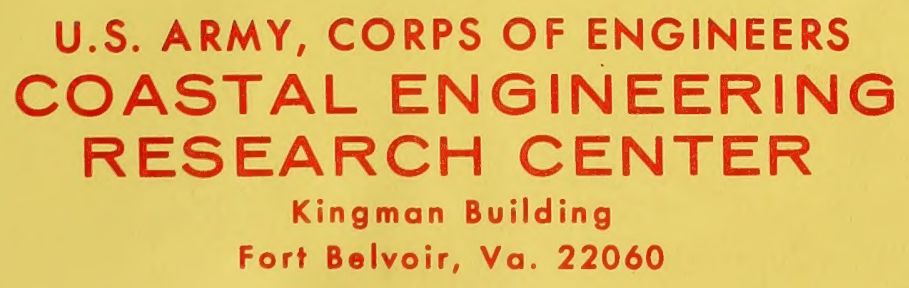

U.S. ARMY, CORPS OF ENGINEERS 
Reprint or republication of any of this material shall give appropriate credit to the U.S. Army Coastal Engineering Research Center.

Limited free distribution within the United States of single copies of this publication has been made by this Center. Additional copies are available from:

\section{National Technical Information Service ATTN: Operations Division 5285 Port Royal Road Springfield, Virginia 22151}

The findings in this report are not to be construed as an official Department of the Army position unless so designated by other authorized documents. 


\begin{tabular}{|c|c|}
\hline REPORT DOCUMENTATION PAGE & $\begin{array}{l}\text { READ INSTRUCTIONS } \\
\text { BEFORE COMPLETING FORM }\end{array}$ \\
\hline $\begin{array}{l}\text { 1. REPORT NUMBER } \\
\text { MR } 78.2\end{array}$ & 3. RECIPIENT'S CATALOG NUMBER \\
\hline \multirow[t]{2}{*}{$\begin{array}{l}\text { 4. TITLE (and Subtitie) } \\
\text { AN ANNOTATED BIBLIOGRAPHY OF } \\
\text { CERC COASTAL ECOLOGY RESEARCH }\end{array}$} & $\begin{array}{l}\text { 5. TYPE OF REPORT \& PERIOD COVERED } \\
\text { Miscellaneous Report }\end{array}$ \\
\hline & 6. PERFORMING ORG. REPORT NUMBER \\
\hline $\begin{array}{l}\text { 7. AUTHOR(s) } \\
\text { Edward J. Pullen, Robert M. Yancey, Paul L. Knuston, and } \\
\text { Arthur K. Hurme }\end{array}$ & 8. CONTRACT OR GRANT NUMBER( $(8)$ \\
\hline $\begin{array}{l}\text { 9. PERFORMING ORGANIZATION NAME AND ADDRESS } \\
\text { Department of the Army } \\
\text { Coastal Engineering Research Center (CERRE-CE) } \\
\text { Kingman Building, Fort Belvoir, Virginia } 22060\end{array}$ & $\begin{array}{l}\text { 10. PROGRAM ELEMENT, PROJECT, TASK } \\
\text { AREA \& WORK UNIT NUMBERS } \\
\text { V04230 }\end{array}$ \\
\hline \multirow{2}{*}{$\begin{array}{l}\text { 11. CONTROLLING OFFICE NAME AND ADDRESS } \\
\text { Department of the Army } \\
\text { Coastal Engineering Research Center } \\
\text { Kingman Building, Fort Belvoir, Virginia } 22060\end{array}$} & $\begin{array}{l}\text { 12. REPORT DATE } \\
\text { MaY } 1978\end{array}$ \\
\hline & $\begin{array}{l}\text { 13. NUMBER OF PAGES } \\
2 \mathscr{2} 21 P \text {. }\end{array}$ \\
\hline \multirow[t]{2}{*}{ 14. MONITORING AGENCY NAME \& ADDRESS(If different from Controlling Office) } & $\begin{array}{l}\text { 15. SECURITY CLASS. (of this report) } \\
\text { UNCLASSIFIED }\end{array}$ \\
\hline & $\begin{array}{l}\text { 15a. DECLASSIFICATION/DOWNGRADING } \\
\text { SCHEDULE }\end{array}$ \\
\hline
\end{tabular}

Approved for public release; distribution unlimited.

17. DISTRIEUTION STATEMENT (of the abstract ontered in Block 20, it different from Report)

18. SUPPLEMENTARY NOTES

19. KEY WORDS (Continue on reverse side if necessary and identlfy by block number)

Annotated bibliography

Coastal ecology

20. ABSTRACT (Coattaue on peverse oide if neceasary and identify by block number)

This bibliography identifies the research work that was either funded by or published by the CERC Coastal Ecology Branch from 1967 to March 1978. 



\section{PREFACE}

This report is published to provide coastal engineers with a comprehensive bibliography of coastal ecology research work. The bibliography is published under the coastal ecology research program of the U.S. Army Coastal Engineering Research Center (CERC).

The report was compiled by Edward J. Pullen, Robert M. Yancy, Paul L. Knuston, and Arthur K. Hurme, under the general supervision of R.P. Savage, Chief, Research Division.

Comments on this publication are invited.

Approved for publication in accordance with Public Law 166, 79th Congress, approved 31 July 1945, as supplemented by Public Law 172, 88th Congress, approved 7 November 1963.

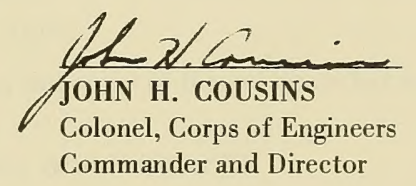


CONTENTS

Page

I INTRODUCTION $\ldots \ldots \ldots \ldots \ldots \ldots \ldots \ldots \ldots \ldots \ldots \ldots \ldots \ldots \ldots \ldots \ldots$

II ANNOTATED BIBLIOGRAPHY $\ldots \ldots \ldots \ldots \ldots \ldots \ldots \ldots \ldots \ldots \ldots \ldots \ldots$

III AUTHOR INDEX . . . . . . . . . . . . . . . . . . . . . . 19

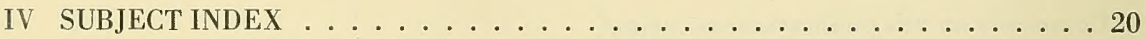




\author{
Compiled by \\ Edward J. Pullen, Robert M. Yancey, Paul L. Knutson, \\ and \\ Arthur K. Hurme
}

\title{
I. INTRODUCTION
}

This bibliography identifies the research work that was either funded by or published by the CERC Coastal Ecology Branch from 1967 to March 1978. Abstracts are provided to assist coastal engineers and scientists in evaluating and selecting pertinent literature for use in environmental studies. Separate author and subject indexes are also included.

Publications that are in stock at CERC are available upon request to the Technical Information Division, Coastal Engineering Information and Analysis Center (CERTI-CE). Interlibrary loans for all CERC publications are made for 90 days on request to the Technical Information Division, Library Branch (CERTI-LI). Publications no longer available at CERC may be purchased by AD Number in hard copy or microfiche from:

National Technical Information Service (NTIS)

ATTN: Operations Division

5285 Port Royal Road

Springfield, Virginia 22151

Suggestions for improving the usefulness and scope of this reference list are solicited.

\section{ANNOTATED BIBLIOGRAPHY}

1967

1. WOODHOUSE, W.W., Jr., and HANES, R.E., "Dune Stabilization with Vegetation on the Outer Banks of North Carolina," TM-22, U.S. Army, Corps of Engineers, Coastal Engineering Research Center, Washington, D.C., Aug. 1967, NTIS AD No. 659341.

Shore and nursery experiments were conducted to develop an accelerated and effective vegetation program for "growing" dunes. Randomized blocks of plantings, with three replications, were used in the experiments. Results of various methods of producing nursery stock transplanting and fertilization, are shown in figures, tables, and photos. The most practical and economical methods for each step of the program are suggested. 
2. SAVAGE, R.P., and WOODHOUSE, W.W., Jr., "Creation and Stabilization of Coastal Barrier Dunes," Proceedings of 11th Conference on Coastal Engineering, London, England, 1968, pp. 671-700 (also Reprint 3-69, U.S. Army, Corps of Engineers, Coastal Engineering Research Center, Washington, D.C., Sept. 1969), AD No. 697532.

This paper presents the results of field experiments to create and stabilize barrier dunes along the North Carolina coast during the past decade. All of the experimental work has been carried out on low-lying barrier islands, a geographical environment typical of most of the Atlantic and gulf coasts of the United States. The experimentation has been directed toward the use of sand fences and dune grasses to catch and hold windblown sand and thus create and maintain a barrier dune.

3. GAGE, B.0., "Experimental Dunes of the Texas Coast," MP 1-70, U.S. Army, Corps of Engineers, Coastal Engineering Research Center, Washington, D.C., Jan. 1970, NTIS AD No. 702902.

Report describes experiments of creating and stabilizing sand dunes to protect the coast. Four locations were selected: the southwest end of Galveston Island, Packery Channel, Newport Pass on North Padre Island, and Corpus Christi Pass. Low areas of the barrier islands were planted in beach grass in an attempt to establish dunes without the aid of sand fences. Snow fencing was used to accumulate windblown sand, and beach grass planted to stabilize dunes. Junk car bodies were placed in line parallel to beaches to establish and stabilize dunes by trapping sand. Since snow fences are more effective and much cheaper, junk cars are not recommended for building dunes.

4. GROSS, M.G., "Preliminary Analysis of Urban Waste, New York Metropolitan Region," Technical Report No. 5, Marine Science Research Center, State University of New York, Stony Brook, Mar. 1970, 35 pp., NTIS AD No. 746959.

Preliminary analyses were made of 17 sewage sludge samples from sewage treatment plants serving 11.9 million persons in the New York metropolitan region. The sludge consisis of about 55-percent organic matter, whicil accounts for about 55 percent of the total oxygen demand. About 45 percent of the sludge is aluminosilicate material, chemically similar to shale. The sludge samples are enriched (compared to sedimentary rocks, soils, and organisms) in the following elements: chromium, copper, lead, and tin. These elements are common industrial materials, and are known to be highly toxic to marine organisms; some are carcinogenic. The preliminary analyses indicate semiquantitative spectrochemical analyses may be useful for determining order-of-magnitude concentrations of 24 elements 
commonly occurring in sewage sludges. Loss-on-ignition, an ashing technique, is useful for the analysis of organic matter in sewage sludges not containing large amounts of hydrous aluminosilicates.

5. GROSS, M.G., "Analysis of Dredged Waste, Fly Ash and Waste Chemicals, New York Metropolitan Region," Technical Report No. 7, Marine Science Research Center, State University of New York, Stony Brook, Oct. 1970, 33 pp., NTIS AD No. 734337.

Chemical and physical properties were determined on wastes commonly transported by barge for disposal in coastal waters offshore from New York Harbor. Dredged wastes were studied by analysis of harbor sediment and wastes deposited in the "mud disposal area." Chemical and physical properties of these wastes suggest that they commonly consist of about 20-percent carbonaceous wastes (possibly sewage solids) mixed with low carbon river-borne silt (median grain size 30 micrometers) and an unknown amount of industrial wastes. Waste chemicals analyzed had a wide range of chemical composition but were not adequately sampled to provide useful limits on their chemical and physical compositions. Some samples of waste chemicals had high concentrations of such metals as lead, tin, and zinc. A preliminary budget of waste solids dumped in the New York Bight indicates that dredged wastes are major sources of oxygen-demanding substances and potentially troublesome metals. Certain metals, especially silver and lead, and the high carbon concentrations are promising as tracers in delineating distributions and subsequent movement of waste deposits in the region.

6. GROSS, M.G., et al., "Survey of Marine Waste Deposits, New York Metropolitan Region," Technical Report No. 8, Marine Science Research Center, State University of New York, Stony Brook, Apr. 1971, 72 pp., NTIS AD No. 723431.

Major sources of wastes and large waste deposits in the coastal waters around the New York metropolitan region were surveyed in 1970 to determine their properties. Using the most diagnostic properties of the wastes, the areas covered by the various waste deposits were sampled and approximate boundaries determined. Distribution of samples containing anomalously high total concentrations of chromium, copper, lead, and silver was compared to the distribution of carbon-rich deposits on the Continental Shelf. Assuming that carbon-rich deposits are indicative of waste accumulation on the Continental Shelf, the data indicate that lead and copper are the most useful elements for mapping and distribution of wastes. Silver is marginally useful for determining waste distributions; total chromium concentrations appear to have little utility. Concentrations of HC1-extractable metals (copper, nickel, chromium, manganese, and iron) correlated well with total elemental concentrations determined by optical emission spectrochemical analyses. 
Only a few groups of pollution-tolerant organisms (nematodes and capitellid worms) were abundant in sediments from the inner parts of New York Harbor. Benthic animal communities in most of the inner harbor were either drastically impoverished or laching; communities in the lower bay were less severely affected by pollution. Near the harbor entrance the Continental Shelf appeared to have near-normal bottom-dwelling organisms. No living forminifera were found in sediment from the East River near Throgs Neck; few species of living foraminifera were present in the western Long Island Sound. The total number of individual foraminifera (live plus dead) increased toward the west. Waste disposal activities have had little demonstrable effect on the diversity or distribution of foraminifera in western Long Island. Margalef's Index of Diversity and the number of genera in each sample indicate low diversity values in the extreme western end of the Sound and near the Connecticut shore. Ostracods were rare.

7. HORNE, R.A., MOHLER, A.J., and ROSSELLO, R.C., "The Marine Disposal of Sewage Sludge and Dredged Spoil in the Waters of the New York Bight," Technical Memorandum No. 1-71, Woods Hole Oceanographic Institution, Woods Hole, Mass., Jan. 1971, NTIS AD No. 722791.

The dumping of sewer sludge and dredge spoil in the waters of the New York Bight and the effect of this waste disposal practice on the marine environment are reviewed. The quantities and composition of these wastes are described together with their physical, chemical, and biological effects on the environment. At the center of the sludge dump the bearing capacity of the waters has been exceeded and an anoxic bottom area is devoid of life form. Both spoil and sludge contain large quantities of toxic heavy metals, and the spoil also contains large quantities of petrochemicals and pesticides.

8. SHERK, J.A., Jr., and O'CONNOR, J.M., "Effects of Suspended and Deposited Sediments on Estuarine Organisms," Chesapeake Biological Laboratory Reference No. 71-4D, Natural Resources Institute, University of Maryland, College Park, Md. 1971, 31 pp. and Appendixes.

This is an annual report summarizing research activities and principal findings from September 1970 to September 1971. Experiments were conducted for testing (a) the lethal effects of sediment concentrations, (b) the effects of sediment on cruising speed and respiration of estuarine fish, and (c) the effects of sediments on feeding rates of various estuarine zooplankters.

\section{2}

9. NATIONAL MARINE FISHERIES SERVICE, "The Effects of Waste Disposal in the New York Bight," Sandy Hook Laboratory, Highlands, N. J., Nine sections, NTIS AD Nos. 739, 531 to 739539 ; Summary Final Report (AD No. 743 936), May 1972.

Short-term studies on the effects of ocean dumping in the New York Bight were conducted for CERC. This report summarizes the hydrographic, geological, chemical, and biological data collected. 
i0. ROUNSEFELL, G.A., "Ecological Effects of Offshore Construction," Journal of Marine Science, Vol. 2, No. 1, 1972, 89 pp. and Appendixes.

An evaluation of current knowledge of the probable ecological effects of various types of offshore construction reveals slight danger from the majority of construction programs. The greatest danger lies in the placement of artificial islands within or too closely adjacent to estuaries where they can significantly affect water exchange, and in the proliferation of water-cooled nuclear powerplants.

11. SHERK, J.A., Jr., and O'CONNOR, J.M., "Effects of Suspended and Deposited Sediments on Estuarine Organisms," Chesapeake Biological Laboratory Reference No. 72-9E, Natural Resources Institute, University of Maryland, College Park, Md., Dec. 1972, 105 pp.

This is an annual report summarizing research activities and findings from September 1971 to September 1972. Sedimentary material can be introduced to or resuspended in the estuarine environment by nature or by man. Data indicate that exposure of estuarine fishes to suspended particulate matter can result in increased mortality and sublethal physiological alterations.

12. WOODHOUSE, W.W., Jr., SENECA, E.D., and BROOME, S.W., "Marsh Building with Dredged Spoil in North Carolina," Bulletin No. 445, Agricultural Experiment Station, North Carolina State University, Raleigh, 29 pp. (also Reprint 2-72, U.S. Army, Corps of Engineers, Coastal Engineering Research Center, Washington, D.C., NTIS AD No. 755178.

The value of tidal marsh for shoreline protection and as a nursery ground and source of energy for a high proportion of commercial and sports fishery species has become widely recognized in recent years. Dredge spoil, produced in the maintenance of navigation channels within sounds and estuaries, may be a means of establishing new marsh to replace some of that which has been lost. Therefore, the possibility exists of combining two desirable objectives in one operation-the stabilization of dredge spoil and the establishment of new tidal marsh. This paper is a progress report on a study initiated in the fall of 1969 designed to explore this possibility.

\section{3}

13. PARARAS-GARAYANNIS, G., "Ocean Dumping in the New York Bight: An Assessment of Environmental Studies," TM-39, U.S. Army, Corps of Engineers, Coastal Engineering Research Center, Fort Belvoir, Va., May 1973, NTIS AD No. 766721.

Short-term studies on effects of ocean dumping in the New York Bight were contracted by CERC. Studies included hydrographic, geological, chemical, and biological investigations, and an electronic sensor survey to detect locations and dump status of waste disposal 
vessels. Circulation patterns were determined. Chemical analyses of water samples were made; sediment and biological samples were analyzed. Included are studies of marine life, bacteria, and waste disposal. Impacts on ecology and water quality are discussed.

14. THOMPSON, J.R., "Ecological Effects of Offshore Dredging and Beach Nourishment: A Review," MP 1-73, U.S. Army, Corps of Engineers, Coastal Engineering Research Center, Washington, D.C., Jan. 1973, NTIS AD No. 756366.

A review of ecological effects of offshore dredging is presented. Although basic ecological works are available, there has been little concrete effort to determine effects of offshore dredging; additional research is needed to approach full understanding. Report shows that a beach may be divided into three zones on the basis of moisture and biota, and describes the possible effects on these biota from offshore dredging and deposition of sediments. Background material and impacts on both offshore dredged areas and nourished beaches, and suggestions for further research are included. A selected bibliography is included.

\section{4}

15. COURTENAY, W.R., Jr., et al., "Ecological Monitoring of Beach Erosion Control Projects, Broward County, Florida, and Adjacent Areas," TM-41, U.S. Army, Corps of Engineers, Coastal Engineering Research Center, Fort Belvoir, Va., Feb. 1974, NTIS AD No. 778733.

Ecological monitoring of algae, invertebrates, and fishes was conducted along the southeast Florida coast in connection with offshore dredging and beach nourishment projects. One area surveyed showed no adverse ecological effects; reef damage by dredging equipment was found in another area. Ecological data have been recorded for three other areas proposed for dredge-and-fill operations.

16. HURME, A.K., "A Glossary of Ecological Terms for Coastal Engineers," MP 2-74, U.S. Army, Corps of Engineers, Coastal Engineering Research Center, Fort Belvoir, Va., Mar. 1974, NTIS AD No. 777764.

This is a glossary of basic ecology terms commonly encountered in the field of coastal engineering. The terms are applicable to, but not necessarily restricted to, marine and freshwater environments of the coastal zone. Terms are cross-referenced and defined in nontechnical language for use by nonecologists.

17. KEITH, J.M., and SKJEI, R.E., "Engineering and Ecological Evaluation of ArtificialIsland Design, Rineon Island, Punta Gorda, California," TM-43, U.S. Army, Corps of Engineers, Coastal Engineering Research Center, Fort Belvoir, Va., Mar. 1974, NTIS AD No. 778740.

Rincon Island is a manmade offshore island composed of armor rock and tetrapod revetments enclosing a sand core. An evaluation after 14 years shows: no damage by waves; littoral transport has been unaffected; little subsidence has occurred; and a thriving community of marine organisms has developed. 
18. SALOMAN, C.H., "Physical, Chemical, and Biological Characteristics of Nearshore Zone of Sandy Key, Florida, Prior to Beach Restoration," Final Report, National Marine Fisheries Service, Panama City, Fla., 1974.

This report defines some of the major physical, chemical, and biological characteristics of the nearshore zone of Sandy Key, Florida, prior to beach restoration. It also includes results of a supplemental study on the effects of hydraulic dredging for emergency restoration of Sunset Beach on Treasure Island, Florida. An extensive bibliography on the physical, chemical, and biological characteristics of the nearshore zone is included.

19. SHERK, J.A., Jr., et al., "Effects of Suspended and Deposited Sediments on Estuarine Organisms," Chesapeake Biological Laboratory Reference No. 74-20, Final Report Natural Resources Institute, University of Maryland, College Park, Md., Mar. 1974, 267 pp., NTIS AD No. A011 372.

A 3-year laboratory study identified the biological effects of (a) suspended mineral solids similar in size to sediments likely to be found in, or added to, estuarine systems in concentrations typically found during flooding, dredging, and disposal of dredged material, and (b) natural sediments. Generally, bottom-dwelling fish species were most tolerant to suspended solids; filter feeders were most sensitive. Early life stages were more sensitive to suspended solids than adults. Carbon assimilation by four species of phytoplankton was significantly reduced by the light attenuating properties of fine silicon dioxide suspensions. Ingestion of radioactive food cells by two species of calanoid copepods was significantly reduced during exposure to suspensions of fuller's earth, fine silicon dioxide, and natural Patuxent River silt.

20. WOODHOUSE, W.W., Jr., SENECA, E.D., and BROOME, S.W., "Propagation of Spartina alterniflora for Substrate Stabilization and Salt Marsh Development," TM-46, U.S. Army, Corps of Engineers, Coastal Engineering Research Center, Fort Belvoir, Va., Aug. 1974, NTIS AD No. 002055.

Describes techniques developed for the propagation of Spartina alterniflora (smooth cordgrass) in the intertidal zone of dredge spoil and eroding shorelines. Both seeding and transplanting methods were successful. The relationship of mineral nutrition to productivity of S. alterniflora was also determined.

\section{5}

21. DAHL, B.E., et al., "Construction and Stabilization of Coastal Foredunes with Vegetation: Padre Island, Texas," MP 9-75, U.S. Army, Corps of Engineers, Coastal Engineering Research Center, Fort Belvoir, Va., Sept. 1975, NTIS AD No. A018 065 .

Experiments to establish specifications and methodologies for beach grasses in constructing and stabilizing foredunes as storm surge barriers along the gulf coast are 
presented. Conclusions are based on 2.5 linear miles of experimental plots with beach plantings and fence-built dunes on Padre Island, Texas. Results of greenhouse experiments on the effects of nutrients and salinity on beach-grass growth are also presented.

22. DODD, J.D., and WEBB, J.W., "Establishment of Vegetation for Shoreline Stabilization in Galveston Bay," MP 6-75, U.S. Army, Corps of Engineers, Coastal Engineering Research Center, Fort Belvoir, Va., Apr. 1975, NTIS AD No. A012 839.

Report discusses the resident species of plants adapted to saline conditions for control of shore erosion in bays and estuaries. The 12 plant species selected are evaluated for their ability to stabilize shorelines. Several combinations of species are suggested for different zones. An inexpensive wave-stilling device to protect plantings from wave action is described.

23. GARBISCH, E.W., Jr., WOLLER, P.B., and McCALLUM, R.J., "Salt Marsh Establishment and Development," TM-52, U.S. Army, Corps of Engineers, Coastal Engineering Research Center, Fort Belvoir, Va., June 1975, NTIS AD No. A014 136.

Establishment and development of vegetation within the intertidal and supratidal zones on salt marshes and dredged materials to stablize shorelines and abate shoreline erosion are reported for the mid-Chesapeake Bay region.

24. HALL, V.L., and LUDWIG, J.D., "Evaluation of Potential Use of Vegetation for Erosion Abatement Along the Great Lakes Shoreline," MP 7-75, U.S. Army, Corps of Engineers, Coastal Engineering Research Center, Fort Belvoir, Va., June 1975, NTIS AD No. A014 137.

This study identifies and evaluates shoreline plants with potential, either alone or in combination with structures, to alter the erosion rate along shores of the Great Lakes. It was determined that plants alone are not suitable erosion controllers along most shores because of severe wave action.

25. NYBAKKEN, J., and STEPHENSON, M., "Effects of Engineering Activities on the Ecology of Pismo Clams," MP 8-75, U.S. Army, Corps of Engineers, Coastal Engineering Research Center, Fort Belvoir, Va., Sept. 1975, NTIS AD No. A016 948.

Three aspects of the ecology of Pismo clams were investigated in Monterey Bay, California: distribution, reproduction cycle, and age and growth. Pismo clam populations were restricted to sand beaches between the Salinas River and Santa Cruz with the highest densities intertidal, and their presence and absence correlated with beach slope and grain size. 
26. SALOMAN, C.H., "A Selected Bibliography of the Nearshore Environment: Florida

West Coast," MP 5-75, U.S. Army, Corps of Engineers, Coastal Engineering Research Center, Fort Bèlvoir, Va., Apr. 1975, NTIS AD No. A012 854.

A collection of over 2,900 references on ecological and coastal engineering subjects related to the nearshore environment of the Florida west coast. References are grouped by subject and alphabetized by author within each subject heading.

1976

27. CAMMEN, L.M., SENECA, E.D., and COPELAND, B.J., "Animal Colonization of Man-Initiated Salt Marshes on Dredged Spoil," TP 76-7, U.S. Army, Corps of Engineers, Coastal Engineering Research Center, Fort Belvoir, Va., June 1976, NTIS AD No. A028 345.

A research study to determine differences in fauna in spoil areas and natural marsh at Drum Inlet and Snow's Cut, North Carolina, is presented. A marked difference in faunal development was found at the sites. Research also showed that planting Spartina on dredge spoil led to the creation of salt marsh which resembled natural marsh.

28. COX, J.L., "Sampling Variation in Sand Beach Littoral and Nearshore Meiofauna and Macrofauna," TP 76-14, U.S. Army, Corps of Engineers, Coastal Engineering Research Center, Fort Belvoir, Va., Sept. 1976, NTIS AD No. A032 115.

This study evaluates sampling procedures and statistical methods for analysis of the fauna associated with high-energy sandy beaches. An extensive one-season sampling at a relatively undisturbed beach site in central Monterey Bay, California, was used as a basis for the evaluation.

29. KNUTSON, P.L., "Summary of CERC Research on Uses of Vegetation for Erosion Control," Proceedings of Great Lakes Vegetation Workshop, Great Lakes Basin Commission and USDA Soil Conservation Service, Dec. 1976, pp. 31-36.

CERC and its predecessor, the Beach Erosion Board, have been investigating uses of vegetation for erosion control for nearly two decades. Early research focused upon dune formation and stabilization with beach grasses. More recently, marsh grasses have been studied as a means of controlling bank erosion. This presentation summarizes important research findings concerning (a) the use of vegetation for the stabilization and formation of dunes, (b) the use of vegetation for bank stabilization, and (c) the use of vegetation in combination with coastal structures. Potential application of these findings in the Great Lakes region is also discussed.

30. LEVY, G.F., "Vegetative Study at the Duck Field Research Facility, Duck, North Carolina," MR 76-6, U.S. Army, Corps of Engineers, Coastal Engineering Research Center, Fort Belvoir, Va., Apr. 1976, NTIS AD No. A025 178.

A vegetative study of the Duck Field Pesearch Facility of the U.S. Army Coastal Engineering Research Center at Duck, North Carolina, was conducted from March 1974 
through June 1975. Eleven different plant communities were delimited. Floristic collections made throughout the study period revealed a flora of approximately 178 species in 132 genera representing 58 families.

31. O'CONNOR, J.M., NEUMANN, D.A., and SHERK, J.A., Jr., "Lethal Effects of Suspended Sediments on Estuarine Fish," TP 76-20, U.S. Army, Corps of Engineers, Coastal Engineering Research Center, Fort Belvoir, Va., Apr. 1976, NTIS AD No. A037 377.

This study provides base-line information for preproject decisionmaking based upon the anticipated concentration of suspended sediments at the project site and the effect of various lengths of exposure on estuarine fish of different life-history stages and habitat preference.

32. OLIVER, J.S., and SLATTERY, P.N., "Effects of Dredging and Disposal on Some Benthos at Monterey Bay, California," TP 76-15, U.S. Army, Corps of Engineers, Coastal Engineering Research Center, Fort Belvoir, Va., Oct. 1976, NTIS AD No. A032 684 .

Natural temporal variations in benthic assemblages and substrate stability changes, effects of dredging and disposal of dredged material, subsequent recolonization and recovery, and faunal distribution and reproductive abilities are discussed.

33. SALOMAN, C.H., "The Benthic Fauna and Sediments of the Nearshore Zone off Panama City Beach, Florida," MR 76-10, U.S. Army, Corps of Engineers, Coastal Engineering Research Center, Fort Belvoir, Va., Aug. 1976, NTIS AD No. A031 992.

This study presents basic scientific data on the benthic fauna and surface sediments of the nearshore zone of Panama City Beach, Florida, before restoration of the beach, and the results of a study on the effect of Hurrican Eloise on the benthic fauna in the swash zone of Panama City Beach.

34. SENECA, E.D., WOODHOUSE, W.W., Jr., and BROOME, S.W., "Dune Stabilization with Panicum amarum Along the North Carolina Coast," MR 76-3, U.S. Army, Corps of Engineers, Coastal Engineering Research Center, Fort Belvoir, Va., Feb. 1976, NTIS AD No. A023 178.

This study was conducted to determine the dune-stabilizing and dune-building potential of Panicum amarum (bitter panicum) along the North Carolina coast. 
35. SHERK, J.A., Jr., O'CONNOR, J.M., and NEUMANN, D.A., "Effects of Suspended Solids on Selected Estuarine Plankton," MR 76-1, U.S. Army, Corps of Engineers, Coastal Engineering Research Center, Fort Belvoir, Va., Jan. 1976, NTIS AD No. A022 653 .

A 3-year laboratory study identified biological components of selected populations of estuarine organisms most sensitive to the effects of different suspended sediments.

36. WEBB, J.W., and DODD, J.D., "Vegetation Establishment and Shoreline Stabilization," TP 76-13, U.S. Army, Corps of Engineers, Coastal Engineering Research Center, Fort Belvoir, Va., Aug. 1976, NTIS AD No. A030 169.

Techniques for shoreline stabilization with vegetation and the associated environment are presented. Studies were conducted on the adaption of species for shoreline stabilization, use of wave-stilling devices, and effects of fertilizers along the north shore of East Bay, Texas.

37. WOODHOUSE, W.W., Jr., SENECA, E.D., and BROOME, S.W., "Propagation and Use of Spartina alterniflora for Shoreline Erosion Abatement," TR 76-2, U.S. Army, Corps of Engineers, Coastal Engineering Research Center, Fort Belvoir, Va., Aug. 1976, NTIS AD No. A030 4.23.

This report contains the results of experiments in the use of marsh vegetation to protect eroding shorelines, a laboratory study on mineral nutrition of Spartina alterniflora, and an additional year of monitoring several trials previously described by these authors.

38. DAHL, B.E., and GOEN, J.P., "Monitoring of Foredunes on Padre Island, Texas," MR 77-8, U.S. Army, Corps of Engineers, Coastal Engineering Research Center, Fort Belvoir, Va., July 1977, NTIS AD No. A043 875.

This study was conducted to continue monitoring foredunes formed from grass planting during 1969 to 1973 on north Padre Island beaches. The report summarizes data obtained from elevational profiles and vegetative transects at one natural foredune and four experimental foredunes during 1975 and 1976.

39 KNUTSON, P.L., "Planting Guidelines for Marsh Development and Bank Stabilization," CETA 77-3, U.S. Army, Corps of Engineers, Coastal Engineering Research Center, Fort Belvoir, Va., Aug. 1977, NTIS AD No. A046 547.

Marsh plants are effective in stabilizing eroding banks in many sheltered coastal areas. This report provides guidelines for (a) selecting plants and planting methods, (b) determining seed application rate and plant spacing, (c) determining fertilization requirements, and (d) estimating labor cost. 
40. KNUTSON, P.L., "Planting Guidelines for Dune Creation and Stabilization," CETA 77-4, U.S. Army, Corps of Engineers, Coastal Engineering Research Center, Fort Belvoir, Va., Sept. 1977, NTIS AD No. A046 170.

Beach grasses have been used successfully in many coastal projects to form and stabilize dune systems as natural barriers to the inland penetration of waves and storm surges. This report provides guidelines for (a) selecting plants and planting methods, (b) obtaining plants; (c) storing, planting, and maintaining plants; and (d) estimating labor requirements.

41. KNUTSON, P.L., "Designing for Bank Erosion Control With Vegetation," Proceedings of Fifth Symposium of the Waterway, Port, Coastal and Ocean Division, American Society of Civil Engineers, Nov. 1977, pp. 716-733 (also Reprint 78-2, U.S. Army, Corps of Engineers, Coastal Engineering Research Center, Fort Belvoir, Va., Feb. 1978), NTIS AD No. A051 571.

Marsh plants are effective in stabilizing eroding banks in sheltered coastal areas. Exceptional results have been achieved in a variety of intertidal environments at a fraction of the cost required for comparable structural protection. Techniques are available for the efficient propagation of several marsh plants for use in bank stabilization. This paper provides design criteria for (a) determining site suitability, (b) selecting plant materials and planting methods, and (c) estimating labor requirements on a project-by-project basis.

42. MATTA, J.F., "Beach Fauna Study of the CERC Fieid Research Facility, Duck, North Carolina," MR 77-6, U.S. Army, Corps of Engineers, Coastal Engineering Research Center, Fort Belvoir, Va., Apr. 1977, NTIS AD No. A040 573.

The results of an intensive seasonal study of the beach fauna of a barrier island in Dare County, North Carolina, are presented. Study areas include the beach face from margin of the swash zone to 60 meters offshore on the ocean beach, and from swash zone to 300 meters offshore on the sound beach. A simple quantitative sampling device was also developed for use in the surf zone.

43. MEYER, A.L., and CHESTER, A.L., "The Stabilization of Clatsop Plains, Oregon," Shore and Beach, Vol. 45, No. 4, Oct. 1977, pp. 34-41.

The Clatsop Plains, Oregon, were successfully stabilized by erecting sand fences to create a base for planting grasses. A protective foredune was formed from the windblown sand collected by sand fences and beach grasses. European beachgrass was planted, followed in later years by plantings of Scotch broom and shore pine. An analysis of successive survey profiles showed that sand accumulated at an average annual rate of 5.56 and 5.57 cubic yards per linear foot of beach between 1934 and 1963 and between 1934 and 1964, respectively. Dunes as high as 25 feet have developed behind the beach. 
44. O'CONNOR, J.M., NEUMANN, D.A., and SHERK, J.A., Jr., "Sublethal Effects of Suspended Sediment on Estuarine Fish," TP 77-3, U.S. Army, Corps of Engineers, Coastal Engineering Research Center, Fort Belvoir, Va., Feb. 1977, NTIS AD No. A040 646.

The objective of this study was to determine the effects, if any, of sublethal concentrations of suspended materials on the fish in estuarine systems. The suspensions were of natural sediment, obtained from the Patuxent River estuary, Maryland, or commercially available fuller's earth.

\section{8}

45. JOHNSON, G.F., and deWIT, L.A., "Ecological Effects of An Artificial Island," Dames and Moore, Los Angeles, Calif. (draft report available; final report in preparation, 1978).

This study documents marine ecological conditions at Rincon Island, located approximately one-half mile offshore between Ventura and Santa Barbara, California, in a depth of 14 meters ( 45 feet). The island, which was constructed between 1954 and 1959 to serve as a permanent platform for oil and gas production, is particularly suitable for ecological study. Habitat features associated with the armor rock and concrete tetrapods surrounding the island support a "microecosystem" which differs in biotic composition from surrounding natural bottom areas.

A major part of the study was devoted to analysis of seasonal dynamics in biotic composition. Permanent transects extending from the high intertidal to natural bottom were established normal to each of the four cardinal sides of the island. All macrobiota were censused in duplicate 1-square meter quadrants along each transect during each of the four seasons. Other studies included a gill net survey of fish fauna, mapping of mussel "talus" beds at the base of the island, and a survey of biota along a natural bottom transect between the island and shore.

46. JOHNSON, G.F., et al., "Ecological Effects of An Artificial Island," Proceedings of Symposium on Technical, Environmental, Socioeconomic and Regulatory Aspects of Coastal Zone Planning and Management, American Society of Civil Engineers, Vol. 4, Mar. 1978.

Rincon Island's rock revetments offer a diversity of habitat features for a great variety of marine species which do not occur in adjacent natural bottom areas. This study added 160 taxa of macrobiota to the master species list for the island, bringing the total to 458 . Densities of 53 common taxa occurring in permanent transects on each of the four sides of the island were analyzed for seasonal variability. Approximately three-fourths of these showed statistically significant variation. Nine distinctly different major species associations were identified on the island. Twenty-three species of fishes were captured in gill nets placed on all four sides of the island. Rockfish, surfperch, toadfish, and swell sharks dominated the catch. The biota along a transect over natural bottom from near the island to shore were considerably lower in abundance or density and in number of species relative to biota at 
corresponding depths on the island's revetments. Natural sediments were dominated by polychaete worms (35 percent of biomass and 50 percent of species), small crustaceans, clams, ribbon worms, and brittle stars.

The construction of Rincon Island has had a major beneficial effect on local ecological conditions. The quarry-rock and tetrapod construction materials offer habitat features which are not found in a natural sedimentary bottom area. The solid substratum is colonized by a high diversity of encrusting and attached biota. Many of these are habitat-forming species in the sense that they provide shelter and food for additional species.

47. KNUTSON, P.L., "Planting Guidelines for Dune Creation and Stabilization," Proceedings of Symposium on Technical, Environmental, Socioeconomic and Regulatory Aspects of Coastal Zone Planning and Management, American Society of Civil Engineers, Vol. 2, Mar. 1978, pp. 762-779.

Foredunes function as a reservoir of sand to nourish eroding beaches during storms, and as a levee to prevent the inland penetration of waves and storm surges. Dunes are usually created and maintained by the action of beach grasses which trap and hold windblown sand. Erosion will occur if this vegetation is damaged by drought, disease, overgrazing, or by waves during severe storms. Damaged or destroyed dune systems can usually be restored by planting beach grasses.

This paper provides guidelines for creating and stabilizing foredunes with vegetation. The guidelines are based on more than two decades of field studies conducted by CERC and others. Specific information is given on recommended plant species, planting techniques, fertilization rates, labor requirements, and expected dune growth rates.

48. WEBB, J.W., and DODD, J.D., "Shoreline Plant Establishment and Use of a Wave-Stilling Device," MR 78-1, U.S. Army, Corps of Engineers, Coastal Engineering Research Center, Fort Belvoir, Va., Jan. 1978.

The establishment and development of smooth cordgrass transplants on a 2-percent slope behind a wave-stilling device constructed of two tiers of tires strung on a cable were monitored along the north shore of East Bay in Texas. Two previous plantings on the sloped area, the first without wave protection and the second behind one tier of tires, were unsuccessful. After a second tier of tires was placed on top of the original tier, enough protection was provided from waves to allow successful planting. A 0.15 -meter buildup of sediment occurred directly behind the barrier.

Smooth cordgrass survival was approximately 50 percent and over 100 stems per meter squared were counted in some areas 1 year after planting. Density and height of smooth cordgrass increased with increasing hours of inundation. Gulf cordgrass, marshhay cordgrass, and saltgrass survived better than smooth cordgrass above mean high water (MHW). At the highest elevation ( 0.6 meter above NHW), survival was limited, regardless of species. Needlegrass rush transplants failed to survive in significant numbers. With adequate wave protection, smooth cordgrass can be established below MHW in estuarine areas. Gulf cordgrass, marshhay cordgrass, and saltgrass can be used above MHW for shoreline protection. 


\section{AUTHOR INDEX}

Author

Reference Number

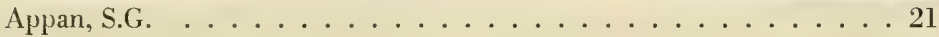

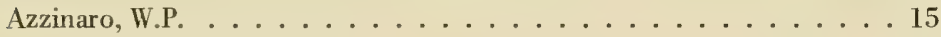

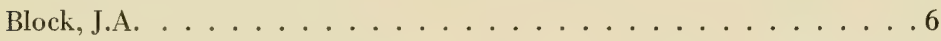

Broome, S.W. . . . . . . . . . . . 12, 20,34,37

Cammen, L.M. . . . . . . . . . . . . . . . 27

Chester, A.L. . . . . . . . . . . . . . . 43

Copeland, B.J. . . . . . . . . . . . . . . 27

Courtenay, W.R., Jr. . . . . . . . . . . . . . 15

Cox, J.L. . . . . . . . . . . . . . . . . . 28

Dahl, L.A. . . . . . . . . . . . . . . . 21, 38

deWit, L.A. . . . . . . . . . . . . . . 45, . 46

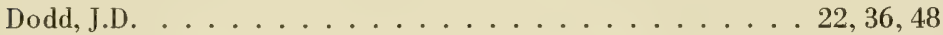

Fall, B.A. . . . . . . . . . . . . . 21

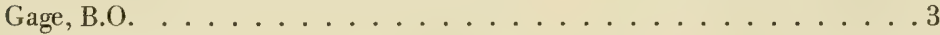

Garbisch, E.W., Jr. . . . . . . . . . . . . . 23

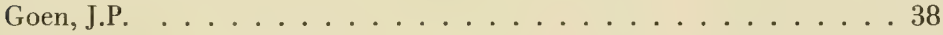

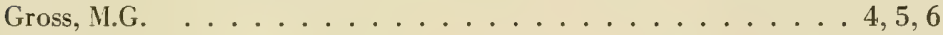

Hall, V.L. . . . . . . . . . . . . . . 24

Hanes, R.E. . . . . . . . . . . . . . . . 1

Herrema, D.J. . . . . . . . . . . . . . 15

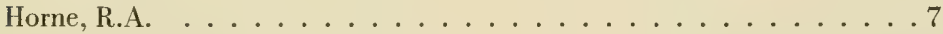

Hurme, A.K. . . . . . . . . . . . . 16, . 16

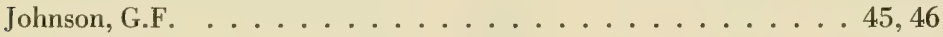

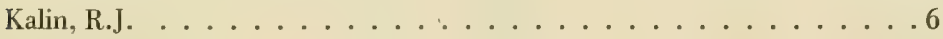

Keith, J.M. . . . . . . . . . . . . . . . . 17

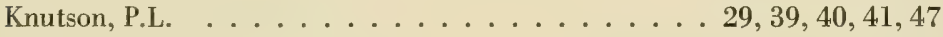

Levy, G.F. . . . . . . . . . . . . . . 30

Lohse, A. . . . . . . . . . . . . . . . 21

Ludwig, J.D. . . . . . . . . . . . . . . . . 24

Matta, J.F. . . . . . . . . . . . . . . 42

McCallum, R.J. . . . . . . . . . . . . . . 23

Meyer, A.L. . . . . . . . . . . . . . 43

Mohler, A.J. . . . . . . . . . . . . . .

Neumann, D.A. . . . . . . . . . . . 19, 31, 35, 44 
Nybakken, J. . . . . . . . . . . . . . . . . . 25

O'Connor, J.M. . . . . . . . . . . . 8, 11, 19, 31, 35, 44

Oliver, J.S. . . . . . . . . . . . . . . . 32

Pararas-Carayannis, G. . . . . . . . . . . . 13

Prince, R.D. . . . . . . . . . . . . . . . . . . . 19

Rossello, R.C. . . . . . . . . . . . . . .

Rounsefell, G.A. . . . . . . . . . . . . 10

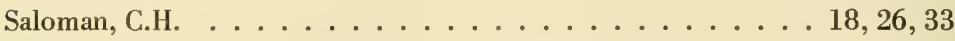

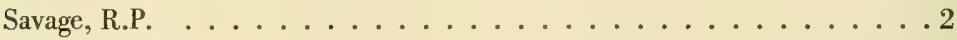

Schramel, J.R. . . . . . . . . . . . . . . . 6

Seneca, E.D. . . . . . . . . . . . 12, 20 27, 34, 37

Sherk, J.A., Jr. … . . . . . . . . . . . 8, 11, 19,31, 35, 44

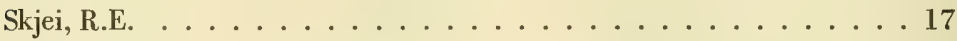

Slattery, P.N. . . . . . . . . . . . . . 32

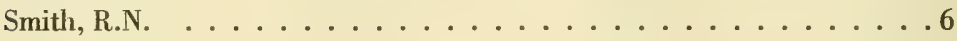

Stephenson, M. . . . . . . . . . . . . . . . 25

Thompson, J.R. . . . . . . . . . . . . . . . 14

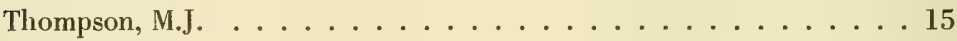

van Montfrans, J. . . . . . . . . . . . . . . . 15

Wales, B.A. . . . . . . . . . . . . . 46

Webb, J.W. . . . . . . . . . . . . 22, 36, 48

Woller, P.B. . . . . . . . . . . . . . . 23

Wood, R.v. . . . . . . . . . . . . . . . . 19

Woodhouse, W.W., Jr. $\ldots \ldots \ldots \ldots \ldots \ldots$. . . 2, 12, 20,34, 37

\section{SUBJECT INDEX}

Subject

Reference Number

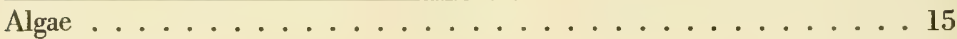

Artificial island . . . . . . . . . 10 10, 17,45,46

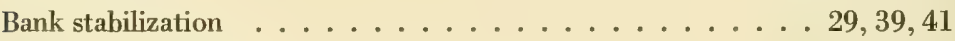

Barrier islands . . . . . . . . . . . . . 2, 3, 30, 38, 42

Beach grass . . . . . . . 1, 2, 3, 21, 29, 30, 34, 38, 40,43,47

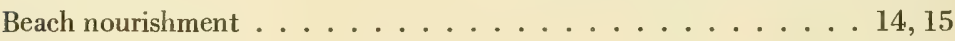

Benthos $\ldots \ldots \ldots \ldots \ldots, 25,28,32,33,45,46$

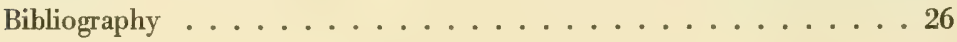


California

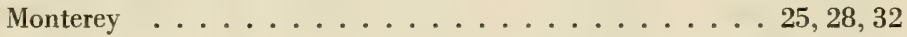

Rincon Island $\ldots \ldots \ldots \ldots \ldots \ldots \ldots \ldots \ldots \ldots \ldots$

Chesapeake Bay Region . . . . . . . . . . . . . 23

Coastal fauna . . . . . 15, 25, 27, 28, 31, 32, 33, 42, 44, 45, 46

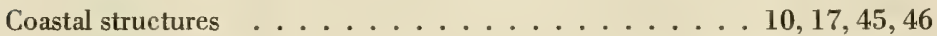

Deposited sediments . . . . . . . . . . 8, 11, 19

Dredged material . . . . . . . . 5, 7, 8, 9, 11, 12, 19, 20, 23

Dune creation . . . . . . . . 1, 2, 3, 21, 29, 34, 40,43,47

Dune stabilization $\ldots \ldots \ldots \ldots 1,2,3,21,29,30,34,40,43,47$

Ecological effects . . . . . . . . . . . 8, 10, 13, 14

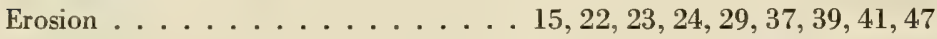

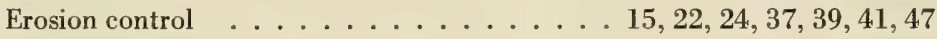

Estuarine fish $\ldots \ldots \ldots \ldots \ldots \ldots$. . . . 11, 19, 31, 44

Estuarine flora . . . . . . . . . . . . . . . 22

Estuarine organisms $\ldots \ldots \ldots \ldots \ldots$. . . . . . . . . . . . 19, 35

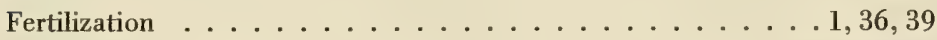

Field Research Facility . . . . . . . . . . . . . . 30,42

Fish $\ldots \ldots \ldots \ldots \ldots . \ldots \ldots, 11,15,19,31,44,45,46$

Florida

Broward County . . . . . . . . . . . . . . 15

Panama City Beach $\ldots \ldots \ldots \ldots \ldots \ldots \ldots$

Southeast coast . . . . . . . . . . . . 15

Treasure Island $\ldots \ldots \ldots \ldots \ldots \ldots$

West coast . . . . . . . . . . . . . 26, 33

Glossary . . . . . . . . . . . . . . . . 16

Great Lakes . . . . . . . . . . . . . . . . 24, 29

Junk car bodies (dunes) $\ldots \ldots \ldots \ldots \ldots$

Littoral transport . . . . . . . . . . . . . 17

Marsh ecology . . . . . . . 12, 20, 23, 27,36,37,39,41

Marsh plants . . . . . . . . . . . . 12, 27,39,41

Maryland

Patuxent River . . . . . . . . . . . . . 19, 44

Nearshore environment . . . . . . . . . . . 26,33

Nearshore zone . . . . . . . . . . . . . . . . . 18,33

New York Bight . . . . . . . . . . . 5, 6, 7,9,13 
North Carolina

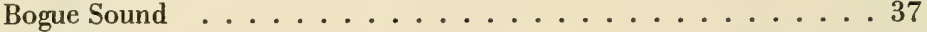

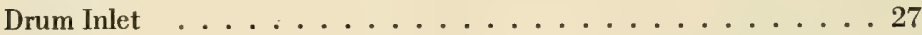

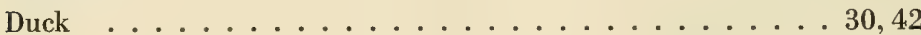

Outer Banks . . . . . . . . . . . . . . . . . 1

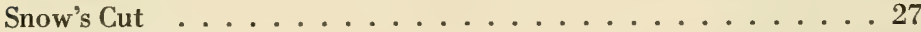

Offshore construction ................ 10

Offshore dredging $\ldots \ldots \ldots \ldots \ldots \ldots \ldots \ldots \ldots \ldots \ldots$

Oregon

Clatsop Plains . . . . . . . . . . . . . 43

Pismo Clams . . . . . . . . . . . . . . . . 25

Plankton . . . . . . . . . . . . . 8, 19, 35

Phytosociology . . . . . . . . . . . . . 30

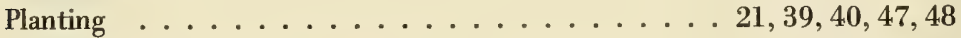

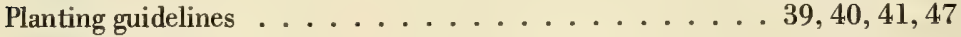

Salinity . . . . . . . . . . . . . . . 22

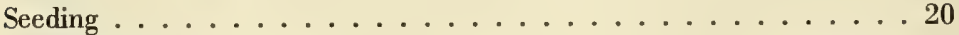

Sewage sludge $\ldots \ldots \ldots \ldots \ldots \ldots \ldots \ldots \ldots \ldots \ldots \ldots \ldots \ldots \ldots$

Shoreline changes . . . . . . . . . . . . . 24

Shoreline stabilization ........... 22, 23, 36

Shore protection . . . . . . . . . . 1, 21, 36, 37, 48

Snow or sand fences (dunes) $\ldots \ldots \ldots . \ldots \ldots . \ldots . . \ldots \ldots$

Soil properties . . . . . . . . . . . . . . . 22

Spoil disposal $\ldots \ldots \ldots . \ldots .4,5,6,7,9,11,12,13,19,27,32$

Substrate stabilization ................. 20

Suspended sediments . . . . . . . . 8, 11, 19, 31, 35, 44

Texas

Corpus Christi Pass . . . . . . . . . . . . 3

East Bay . . . . . . . . . . . . . 22, 36, 48

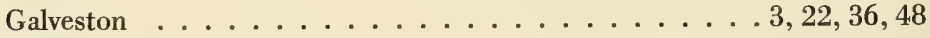

Packery Channel . . . . . . . . . . . . . . . 3

Padre Island . . . . . . . . . . . . . . . . . . 38

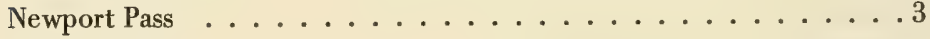

Upper coast . . . . . . . . . . . . . . . 22

Vegetation ......... 1, 2, 12, 20, 21, 22, 23, 24, 27, 29, 30, $34,36,37,38,39,40,41,43,47,48$

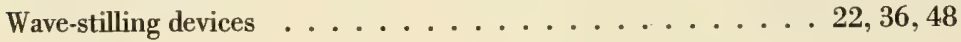




\begin{tabular}{|c|c|c|c|c|c|c|c|c|c|c|c|}
\hline 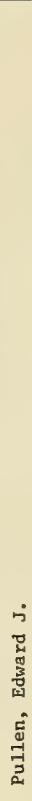 & 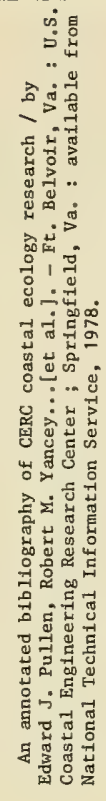 & 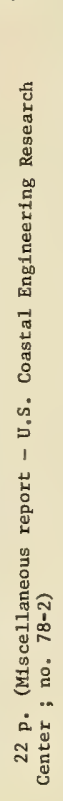 & 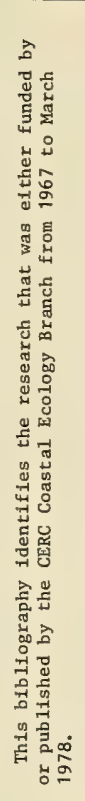 & 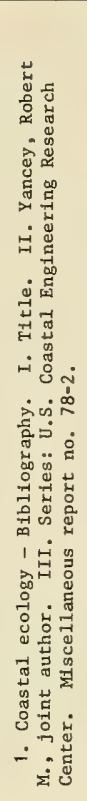 & 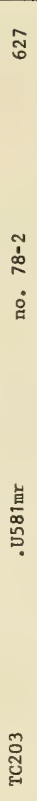 & 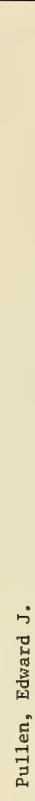 & 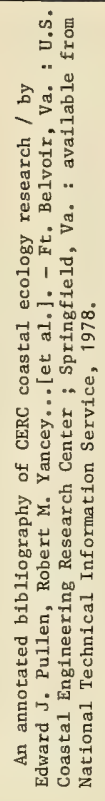 & 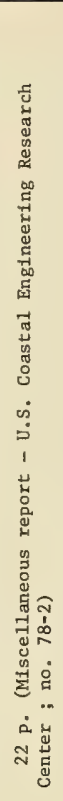 & 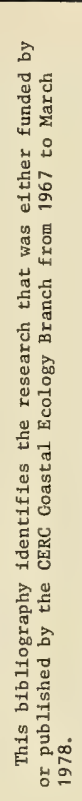 & 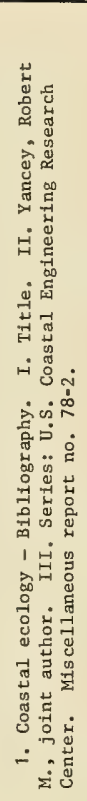 & $\begin{array}{l}\text { 崱 } \\
\text { 吕. }\end{array}$ \\
\hline 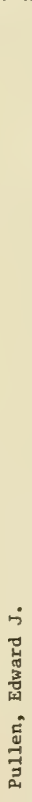 & 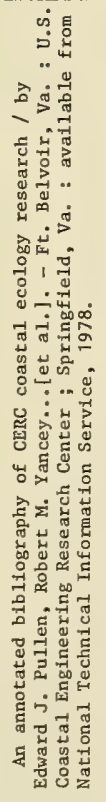 & 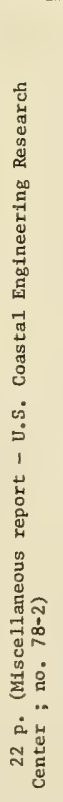 & 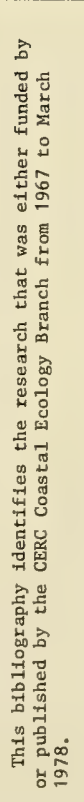 & 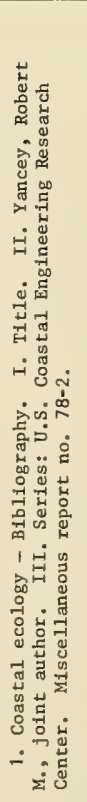 & 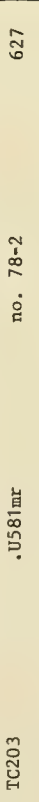 & 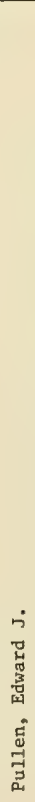 & 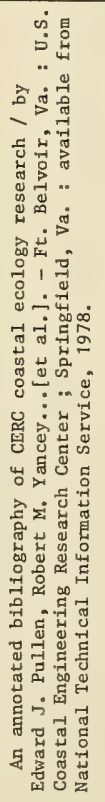 & 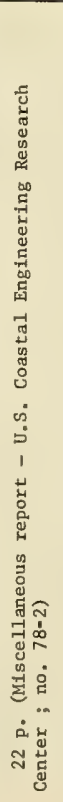 & 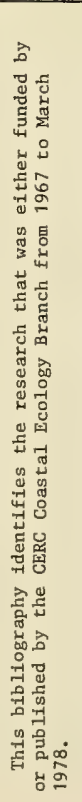 & 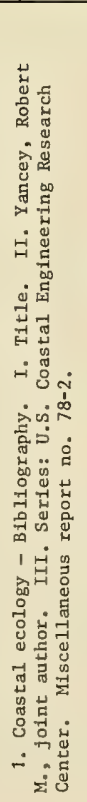 & $\begin{array}{l}\text { 宸 } \\
\text { 号 } \\
\text { ?. }\end{array}$ \\
\hline
\end{tabular}





\begin{tabular}{|c|c|c|c|c|c|c|c|c|c|c|c|}
\hline 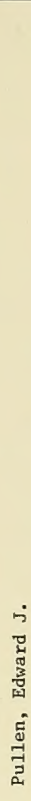 & 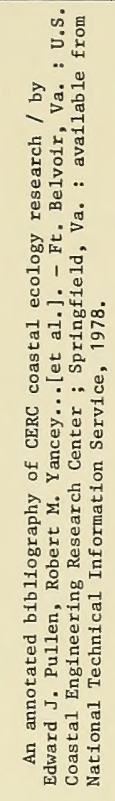 & 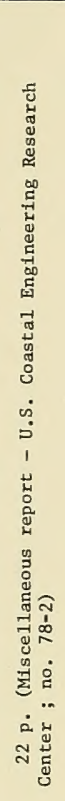 & 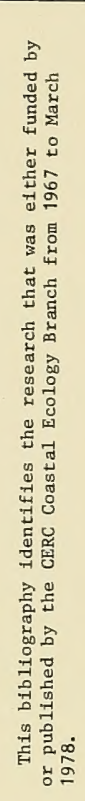 & 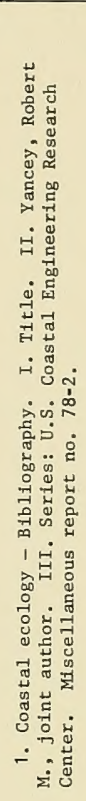 & $\begin{array}{l}\stackrel{1}{1} \\
\stackrel{2}{\sim} \\
\dot{g}\end{array}$ & 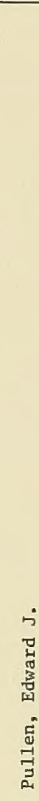 & 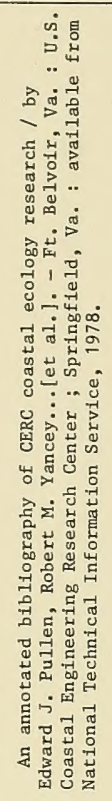 & 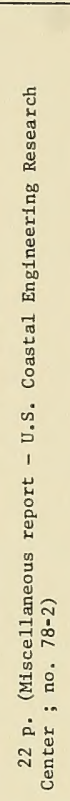 & 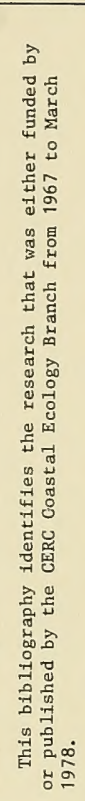 & 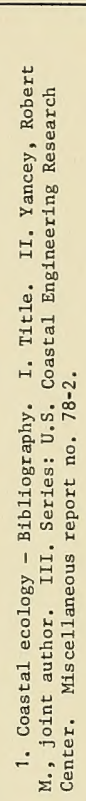 & ્ֻ \\
\hline 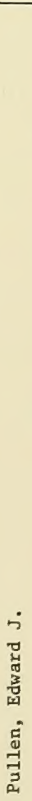 & 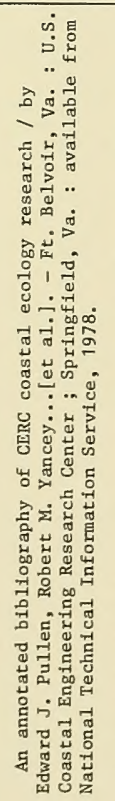 & 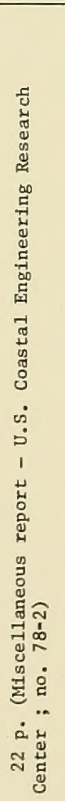 & 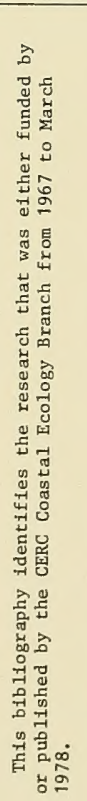 & 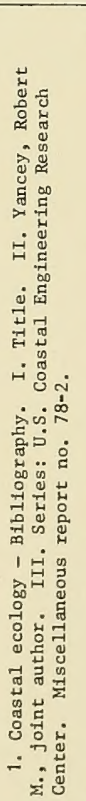 & $\begin{array}{l}\text { 峘 } \\
0 \\
\text { !n }\end{array}$ & 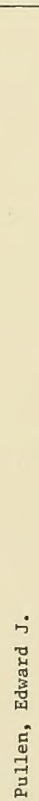 & 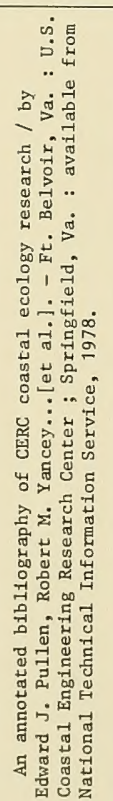 & 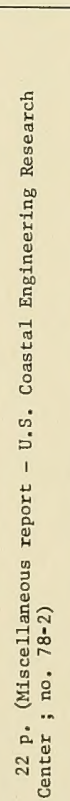 & 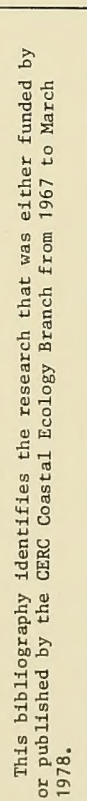 & 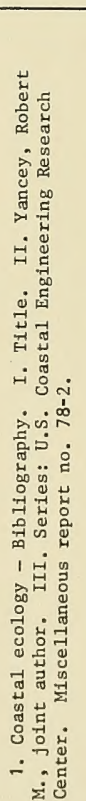 & $\begin{array}{l}\text { 真 } \\
\infty \\
\text { 号. }\end{array}$ \\
\hline
\end{tabular}




